\title{
Spatial and temporal variability of climatic seasons on the East European Plain in relation to large-scale atmospheric circulation
}

\author{
Jaak Jaagus*, Jaak Truu, Rein Ahas, Anto Aasa \\ University of Tartu, Vanemuise 46, 51014 Tartu, Estonia
}

\begin{abstract}
Start date and duration of climatic seasons on the East European Plain (EEP) are analysed. Climatic seasons are determined using daily mean temperatures. Data on climatic seasons are created for 73 stations in the period 1946-1995 and for 12 stations in the period 1881-1995. Climatic seasons of the first half of the year begin first on the northern coast of the Black Sea and last at the northeastern stations. The start of early spring is observed in March and April, the start of spring in April and May, and the start of summer in May and June. Climatic seasons in the second half of the year begin first in the northeast and last in the south. The influence of the Black and Baltic Seas on the retardation of the onset of climatic seasons is remarkable. Autumn usually starts in August and September, late autumn in September and October, and winter in October-December. Duration of summer extends from $5 \mathrm{mo}$ in the south to less than $1 \mathrm{mo}$ in the north, and the duration of winter from $7 \mathrm{mo}$ in the northeast to less than $3 \mathrm{mo}$ in the south. The duration of the intermediate seasons is longer in the western EEP and shorter in the eastern EEP. Some time series of start date and duration of climatic seasons on the EEP have a significant trend. In the western part, the beginning of early spring has shifted up to 1 mo earlier. Correspondingly, the duration of winter has decreased, and the durations of early spring and spring have increased. Using principal component and cluster analyses, regionalisation schemes of the EEP, based on start dates of climatic seasons, are worked out for every season separately and for all the seasons together. The summary regionalisation distinguished Temperate and Sub-Arctic climatic zones, boreal and sub-boreal sub-zones within the Temperate Zone and regions in every zone and sub-zone. Start dates of climatic seasons are correlated with a great number of parameters of atmospheric circulation. Dependence of climatic seasons on atmospheric circulation is analysed and discussed.
\end{abstract}

KEY WORDS: Climatic season - Air temperature - Principal component analysis - Cluster analysis · Climate change $\cdot$ Atmospheric circulation $\cdot$ Eastern Europe

Resale or republication not permitted without written consent of the publisher

\section{INTRODUCTION}

Climate in the Temperate Zone is defined by the alternation of clearly distinguished cold and warm seasons. Usually, monthly mean temperatures are used to represent seasonal cycling. Climatic seasons can be applied as an alternative approach instead of monthly means. Climatic seasons are characterised by their start dates and duration. They start every year at a different time depending on weather conditions. The onset of a climatic season can be observed as a phenological phenomenon.

Climatic seasons are widely used in climatology. The most popular climatic season, the thermal growing season, has been studied in many regions (Jones \& Briffa 1995, Carter 1998, Menzel \& Fabian 1999, Roltsch et al. 1999, Menzel 2000, Schwartz \& Reiter 2000). It has direct importance for agriculture. Climatic seasons have been determined and studied following different criteria (Flohn 1942, Temnikova 1958, Gala- 
hov 1959, Raik 1963, Lamb 1972, Hlavaè 1975, Kalnicky 1987, Sladek 1990, Lewik 1996). As a rule, constant temperature thresholds are used.

In a previous paper (Jaagus \& Ahas 2000), climatic seasons for Estonia were described and their spatiotemporal variability was analysed. Here, a much wider territory, the East European Plain, is investigated. This is a very suitable region for such research. It is a vast flat area where the influence of mountains is practically eliminated. The wide latitudinal extension represents a spectrum of vegetation zones between the north and the south. Continentality of climate is the second main factor, increasing from the west to the east.

The objectives of this study are the following:

- to analyse the spatial distribution of the start date and duration of climatic seasons;

- to estimate their temporal variability and long-term trends;

- to develop a regionalisation scheme using the data on climatic seasons; and

- to analyse the influence of atmospheric circulation on the start date and duration of the climatic seasons.

\section{AREA, DATA AND METHODS}

2.1. Study area. The East European Plain is defined here as the European part of the former Soviet Union except its southernmost regions. It is limited by the geographical co-ordinates $46-69^{\circ} \mathrm{N}$ and $20-61^{\circ} \mathrm{E}$. This area is mostly plain, partly embracing the Ural Mountains in the east and the Carpathians in western Ukraine. The territory under investigation encompasses Estonia, Latvia, Lithuania, Belarus, the Ukraine, and Moldova in their entirety and the Russian Federation and Kazakhstan in part.

2.2. Air-temperature data. Daily mean air temperature obtained from the database of the All-Russian Research Institute of Hydro Meteorological Information-World Data Centre (www.meteo.ru) served as initial data for determining climatic seasons. In general, these time series are presented for the period 1881-1995. Altogether 73 stations located in the study area were used (Fig. 1).

The majority of these stations have observation data for much less than the $115 \mathrm{yr}$, with a lot of gaps especially during the 2 world wars. Only 12 stations have a nearly continuous time series. They are used for analysing long-term trends in parameters of climatic seasons. The main period for statistical analyses is the 50 yr period 1946-1995.

Homogeneity of the temperature data is unknown. It can be presumed that there is a number of inhomogeneities due to station relocation and urban effects.
Results of time series analysis at different stations were carefully compared, and clearly inhomogeneous time series were not distinguished.

2.3. Determining climatic seasons. Start dates of 6 climatic seasons are used in this study. They are determined using daily mean temperatures. Temperature thresholds of $0,+5$ and $+13^{\circ} \mathrm{C}$ are applied for separating climatic seasons. Early spring begins when the daily mean temperature permanently remains above $0^{\circ} \mathrm{C}$. Spring begins when the temperature crosses $+5^{\circ} \mathrm{C}$ and summer when it is permanently above $+13^{\circ} \mathrm{C}$. The start of autumn corresponds to a fall in temperature below $+13^{\circ} \mathrm{C}$, late autumn below $+5^{\circ} \mathrm{C}$, and winter below zero. Description of the technique for estimation of permanent rises and falls above/below certain temperature limits is presented in Jaagus \& Ahas (2000).

Once the temperature threshold has been reached, positive and negative differences of daily temperature minus the threshold value are summed separately. If the absolute value of the sum of negative differences is higher than the sum of positive differences, then the first crossover of the temperature threshold is not taken as the start of the respective season, and the search for the season's start is continued from this day. Duration of climatic seasons is calculated as the difference between beginning dates of consecutive seasons.

As a result, 2 data sets of different numbers of years and stations were prepared. It was possible to create a long series of start dates and durations of climatic seasons during the whole study period (1881-1995) for 12 stations. Shorter time series were available for 73 stations over 50 yr (1946-1995).

Gaps in the time series are filled using data from neighbouring stations that have the highest correlation. Thereby, the start dates are not interpolated; instead, only values observed at the stations are used. This method is specifically applicable for this type of data. The created data sets can be considered to be phenological because the variables used are in the form of dates.

2.4. Data on large-scale atmospheric circulation. There are 2 main approaches for describing atmospheric circulation quantitatively. The first one is to elaborate a classification scheme for circulation. In that case, a circulation type is determined for every day by comparing the observed air-pressure field with standard fields of the circulation types. Frequency of different circulation types is a quantitative measure of circulation.

A subjective circulation classification worked out in the Arctic and Antarctic Research Institute (St. Petersburg) by G. Ja. Vangengeim (1952) and A. A. Girs (1971) is the most appropriate for the East European 


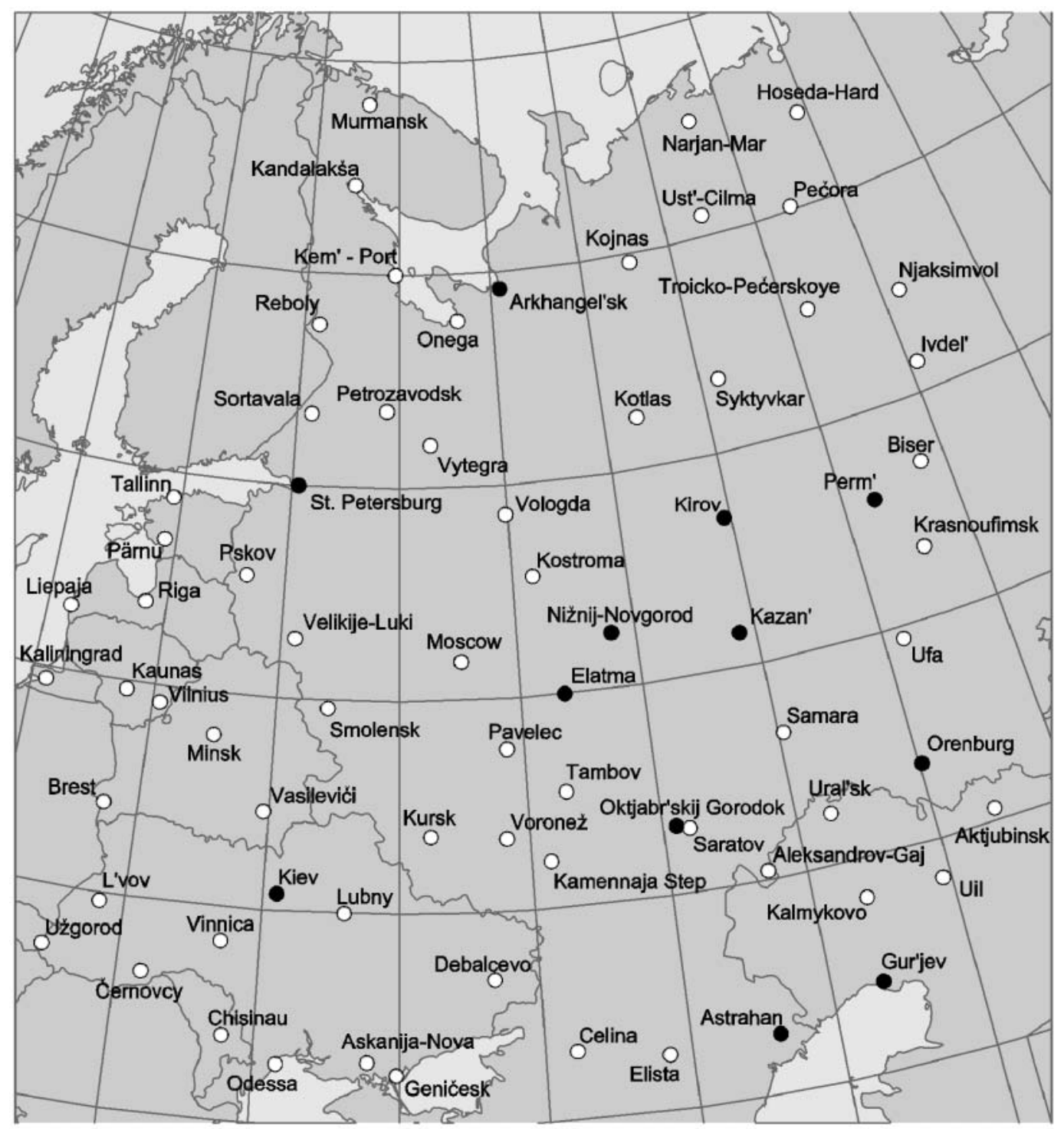

Fig. 1. Location map of stations. Those with a long observation period (1881-1995) are marked with black circles

Plain. There are 3 main circulation forms: W-western zonal; E-eastern, southeastern and southern meridional; and C-northern meridional (Lamb 1972, Kożuchowski \& Marciniak 1988).

Another possibility for characterising large-scale atmospheric circulation is to compose circulation indices. They express the intensity of circulation in a certain region and in certain directions. For example, the North Atlantic Oscillation (NAO) index is a measure of intensity of westerlies in the Atlantic-European sector. In this study, $2 \mathrm{NAO}$ indices-NP, calculated using data from Ponta Delgada, Azores (Hurrell \& van Loon 1997; Climate Analysis Section, University Corporation for Atmospheric Research [www.cgd.ucar. edu/cas/catalog/climind]), and NG, calculated using data from Gibraltar (Jones et al. 1997; Climate Reseach Unit, University of East Anglia [www.cru.uea.ac.uk/ cru/data]) - and the Arctic Oscillation (AO) index (Thompson \& Wallace 1998) are used to describe zonal circulation.

A valuable source of data on large-scale atmospheric circulation are the tele-connection indices for the Northern Hemisphere-available since 1950-worked out by Barnston \& Livezey (1987) using principal component analysis (PCA). Monthly values are presented and updated by the NOAA Climatic Prediction Centre (CPC; www.cpc.noaa.gov/data). There are 7 tele-connection patterns that have a remarkable influence on climate variability in Eastern Europe. The North Atlantic Oscillation (NT), the East Atlantic (EA), 
the East Atlantic Jet (EJ), and Polar/Eurasia (PE) patterns describe mostly zonal circulation at different latitudes and in different seasons, while the East Atlantic/West Russia (EW), Scandinavian (SC), and Asian Summer (AS) patterns describe meridional circulation. Time series of the tele-connection indices started after 1950.

2.5. Methods of statistical analysis. Common statistical measures such as means, standard deviations, and extremes are calculated for the estimation of spatial and temporal variability of climatic seasons. Spatial standard deviation is calculated using mean values from all stations. Temporal standard deviation is computed for the time series of every station. Mean values and temporal standard deviations are mapped.

Linear regression analysis is used to detect changes in time series of climatic seasons. In this paper, change by trend is expressed in days per the total observation period. It means that slope is multiplied by the number of years (115 for the long period and 50 for the short one). Trends are considered significant on the $p<0.05$ level.

S-mode PCA with varimax normalised rotation is applied for elaboration of regionalisation schemes of start date of single climatic seasons for the East European Plain. It is assumed that independent components reflect the influence of independent factors that determine climatic seasons. The 10 first components are computed. Eigenvalues indicate the weight of every component in the total variation. Factor loadings are analysed for every station.

Grouping of stations is made very simply. A component with maximum correlation is determined for every station. Hence, groups of stations are formed that have the highest correlation with the first, second, third, etc., component. The first component, which explains the greatest part of the total variation, usually includes the largest number of stations, while the last components are highly correlated with only very few stations located in peripheral areas.

As a result, there will be 8 to 10 groups of stations. Each group is related to $1 \mathrm{PC}$, which has the highest correlation with the studied variable at the stations in this group. In an intermediate case, when a station has similar correlation with 2 components, it is arbitrarily added to 1 of the 2 groups according to geographical proximity. Location of these groups of stations is presented on classification maps, with groups of stations being distinguished by the use of different symbols to indicate locations of stations.
PCA is applied for the start date data of all 6 climatic seasons separately. Therefore, spatial classification schemes are composed for every variable. In the final stage, a summary classification is made using start dates of the 6 climatic seasons for 50 yr for every station (matrix with 73 rows and 300 columns). T-mode PCA is carried out on a correlation matrix that allows equal contribution of all variables to the clustering of stations.

Further, this pooled data set is used for cluster analysis. Cluster analysis is performed using the pair-wise Pearson's product-moment correlation coefficient and by applying the unweighted arithmetic average clustering method.

The relationship between atmospheric circulation and start dates of climatic seasons is analysed by the use of correlation analysis. The drawing of correlation maps allows estimation of the spatial patterns of these relationships. Correlation between start dates and durations of climatic seasons and parameters of atmospheric circulation is analysed for single seasons using groups of stations determined by the regionalisation procedure. Correlation is also calculated between atmospheric circulation and time series of the scores of different PCs.

2.6. Spatial representation of results. Results of statistical analyses are mostly presented using cartograms and isoline maps. The cartograms are interpolated using inverse distance interpolation, but isoline maps are created by means of kriging. Maps are calculated via simple extrapolation in border areas (Scandinavia, Poland, Romania, etc.) where no data were used. Therefore, their presentation is not reliable.

\section{SPATIAL VARIABILITY}

Climatic seasons have a remarkable spatial variability on the East European Plain. Table 1 presents means, ranges, and spatial standard deviations of start dates and durations of climatic seasons, calculated

Table 1. Mean values, spatial ranges and standard deviations of start date and duration (in days) of the climatic seasons averaged over the whole East European Plain (73 stations) in 1946-1995

\begin{tabular}{|c|c|c|c|c|c|c|}
\hline \multirow{2}{*}{$\begin{array}{l}\text { Climatic } \\
\text { season }\end{array}$} & \multicolumn{2}{|c|}{ Average } & \multicolumn{2}{|c|}{ Range } & \multicolumn{2}{|c|}{ Standard deviation } \\
\hline & $\begin{array}{l}\text { Start } \\
\text { date }\end{array}$ & Duration & $\begin{array}{l}\text { Start } \\
\text { date }\end{array}$ & Duration & $\begin{array}{l}\text { Start } \\
\text { date }\end{array}$ & Duration \\
\hline Early spring & $26 \mathrm{Mar}$ & 23.1 & 94 & 33 & 17.7 & 7.5 \\
\hline Spring & 18 Apr & 34.1 & 84 & 24 & 17.9 & 6.4 \\
\hline Summer & 23 May & 106.2 & 77 & 138 & 19.4 & 36.6 \\
\hline Autumn & $6 \mathrm{Sep}$ & 40.7 & 72 & 30 & 17.7 & 6.8 \\
\hline Late autumn & 17 Oct & 26.1 & 67 & 28 & 15.6 & 6.4 \\
\hline Winter & $12 \mathrm{Nov}$ & 135.6 & 82 & 173 & 20.3 & 37.4 \\
\hline
\end{tabular}


over all the 73 stations. For example, the maximum range of start dates - $94 \mathrm{~d}$ in early spring — signifies the difference between the earliest mean date (15 February in Užgorod) and the latest one (19 May in Hoseda-Hard). There are 2 principal climatic seasons - summer and winter-with 2 intermediate seasons (early spring and spring) before and 2 (autumn, late autumn) after summer. Winter is altogether the longest climatic season. In general, comparatively long main seasons and short intermediate seasons are typical for areas of continental climate. The highest spatial variability is revealed for start date and duration of summer and winter.

Spatial distribution of average start dates of the climatic seasons in the East European Plain is shown in Fig. 2. Isolines are mostly oriented in a west-east direction. The influence of the Baltic and Black Seas is revealed during the cold half-year. Early spring starts much earlier in the coastal stations than in the inland ones (Fig. 2a). At the same time, the start of the summer season is late on the Baltic coast (Fig. 2c). Spring season begins first in the southwest and last in the northeast.

The patterns of start date of autumn and late autumn are rather similar (Fig. 2d,e). Direction of onset of autumn and late autumn is opposite to that of spring and summer. All the maps indicate that the lowest density of isolines is located in the central part of the East European Plain. This is the most homogeneous region, with rather similar climatic conditions. The northern, southern and western regions are characterised by higher density of isolines, i.e. by higher spatial variability. The most remarkable gradient in the start date of winter can be observed in the Baltic countries and Ukraine, where isolines lie parallel to the coastal zone (Fig. 2f).

Duration of climatic seasons on the East European Plain is also very variable (Fig. 3). Two main regularities can be derived. Duration of summer is the longest in the southernmost part of observed territory and the shortest on the northern coast (Fig. 3b), while the pattern of winter duration is directly the opposite (Fig. 3d).

Table 2. Temporal standard deviations of start date and duration (in days) of the climatic seasons averaged over the 73 stations

\begin{tabular}{|lcc|}
\hline Climatic season & Start date & Duration \\
\hline Early spring & 13.9 & 13.8 \\
Spring & 10.1 & 15.0 \\
Summer & 12.3 & 16.2 \\
Autumn & 10.9 & 15.0 \\
Late autumn & 11.0 & 16.8 \\
Winter & 14.6 & 20.4 \\
\hline
\end{tabular}

The intermediate seasons are the longest in the western part of the study area, especially in the Baltic states. Therefore, winter is shorter there in comparison with more eastern areas. The shortest duration of intermediate seasons is observed in the southeastern part of the Plain, in Kazakhstan. The autumn season also tends to be longer in northern Russia due to the influence of warmer airflow from the Barents Sea.

\section{TEMPORAL VARIABILITY AND TRENDS}

\subsection{Short period (1946-1995)}

Temporal standard deviation of climatic seasons is one of the best characteristics of their temporal variability. Mean standard deviations calculated for the period 1946-1995 and averaged over all of the stations are presented in Table 2. The highest fluctuations of start date are typical for winter and early spring. The least variable are the start dates of spring, autumn and late autumn. Duration of winter varies the most substantially.

Temporal variations of start date and duration of climatic seasons have different ranges. In general, standard deviation in the Baltic region and Ukraine is higher than in central Russia and in western Kazakhstan (Fig. 4). This can be explained by higher temporal variability due to more intensive cyclonic activity and more frequent alternation of air masses of different origin.

Linear regression analysis produced a number of statistically significant trends during the period 1946-1995 that reflect general climate warming. But these changes are not equal over the whole East European Plain. For example, the start of early spring has shifted earlier only in the western part, especially in the Baltic Sea region (Fig. 5a). Duration of early spring has also increased on the same territory.

Onset of spring has not changed very much. A negative shift (i.e. to an earlier time) has been detected only for stations in the southeast, on the Caspian lowland. Spring has been significantly shortened in the far northeast (Narjan-Mar and Hoseda-Hard) and lengthened in Ukraine and Moldova (Fig. 5b). Significant changes in the summer season have taken place at the same 2 stations in the northeast. Start of summer has moved earlier by approximately 1 mo and, correspondingly, its duration has increased by the same period. Lengthening of the summer season was also observed in some stations in western Kazakhstan.

There are few significant trends in parameters of climatic seasons during the second half-year. The only exception is southern Ukraine where winter has a significant negative trend, i.e. a shift to the earlier time. In 


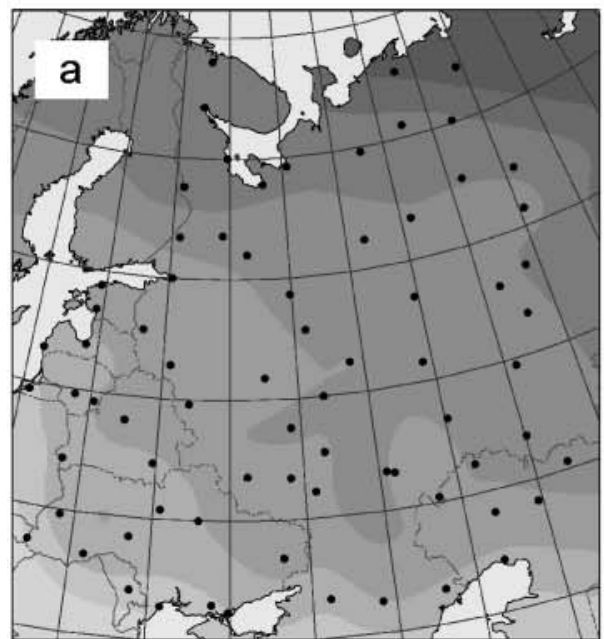

\begin{tabular}{|l|l|l|}
\hline $15-$ Feb & $28-$ Mar $\square 09-$ May \\
$01-$ Mar & $11-$ Apr & $23-$ May \\
$14-$ Mar & $25-$ Apr &
\end{tabular}

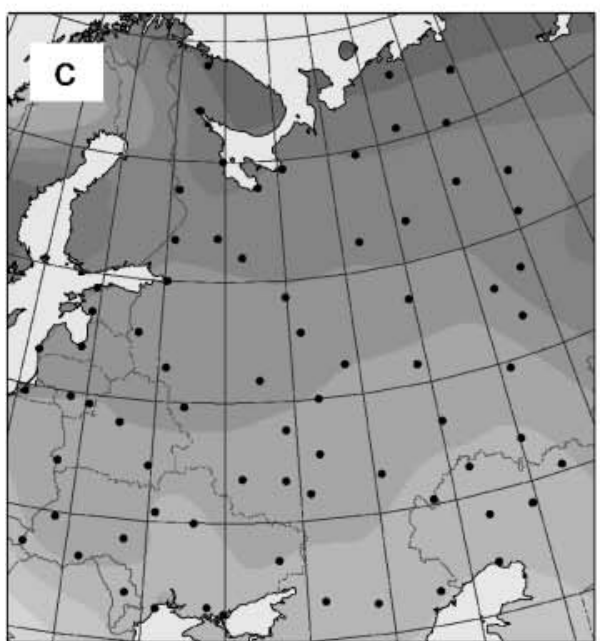

25-Apr
05-May $\begin{aligned} & \text { 25-May } \\ & \text { 04- Jun }\end{aligned} \quad \begin{aligned} & \text { 24 - Jun } \\ & \text { 15- Jul }\end{aligned}$ 15-May 14 - Jun 14 - Jul

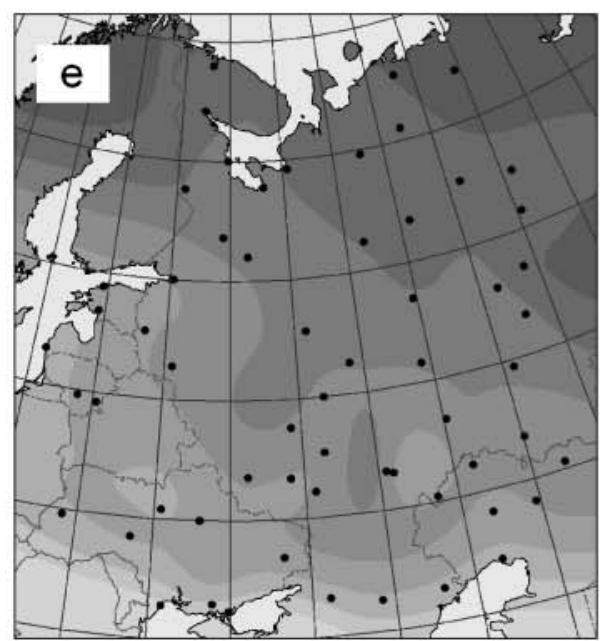

\begin{tabular}{r|r|r}
20 - Sept & 20 - Oct $\square$ 19 - Nov \\
30 - Sept & 30- Oct $\square$ \\
29 & - Nov
\end{tabular} 10. Oct $\quad 09$ - Nov

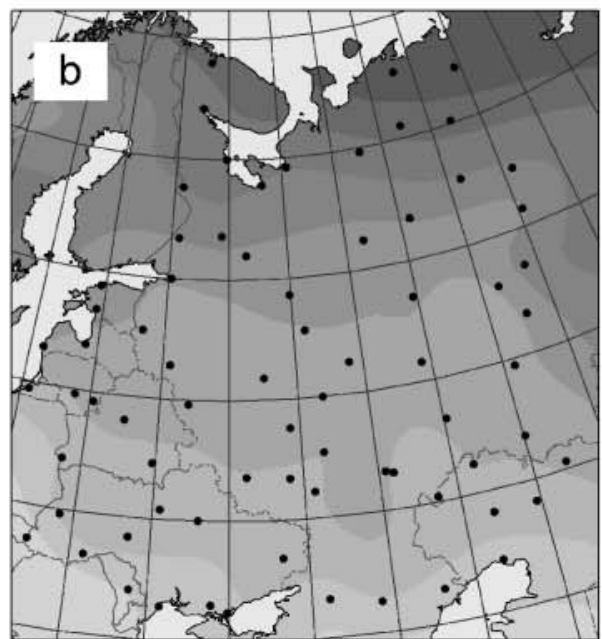

\begin{tabular}{|lll}
\hline 21-Mar & 20-Apr & 20-May \\
31-Mar & 30-Apr & 30-May \\
10-Apr & 10-May & 09-Jun
\end{tabular}

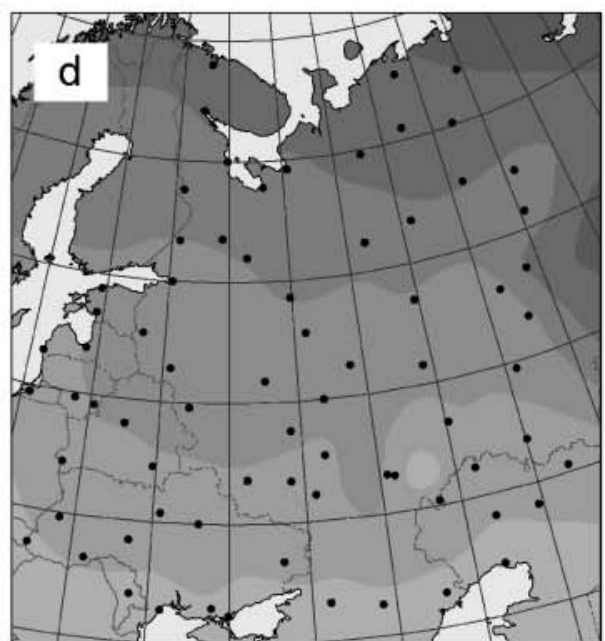

$\begin{array}{ll}01-\text { Aug } & 31 \text { - Aug } \\ 11-\text { Aug } & 10-\text { Sept } \\ 21-\text { Aug } & 20-\text { Sept }\end{array}$

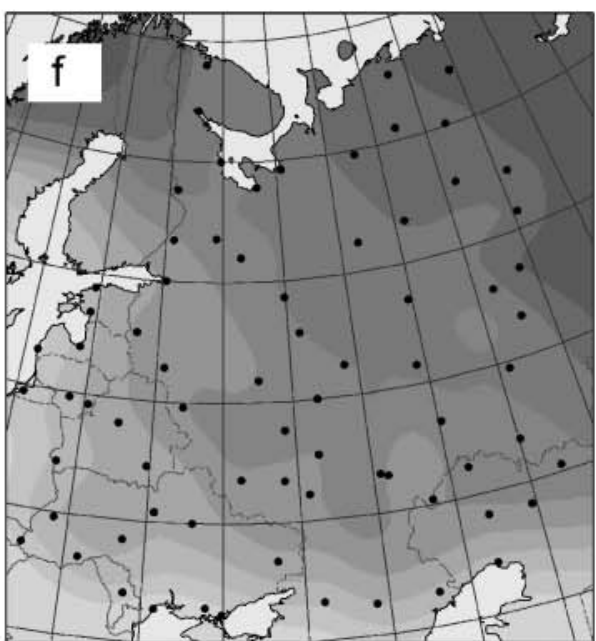
$\begin{array}{lll}10 \text { - Oct } & 09 \text { - Nov } \\ 20 \text { - Oct } & \text { 19-Nov } & 09 \text { - Dec } \\ 30 \text { - Oct } & \text { 29-Nov } & 19 \text { - Dec } \\ \square & 29 \text { - Dec }\end{array}$

Fig. 2. Mean start date of climatic seasons (73 stations, 1946-1995): (a) early spring, (b) spring, (c) summer, (d) autumn, (e) late autumn and (f) winter 


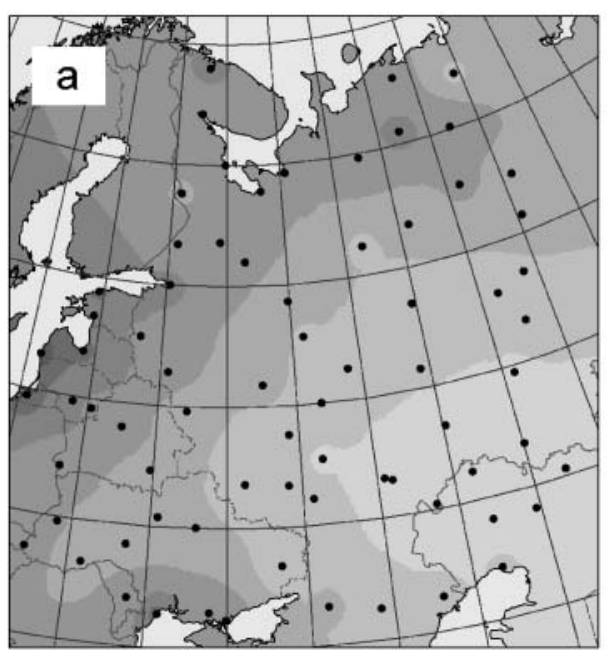

$\square \begin{aligned} & 10-15 \\ & 15-20\end{aligned} \square \begin{aligned} & 25-30 \\ & 30-35\end{aligned} \square 40-45$ $20-25=35-40$
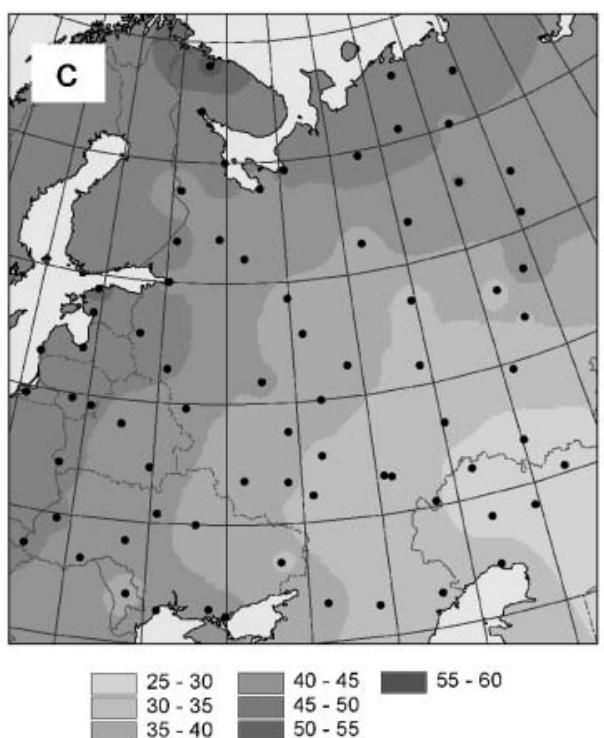

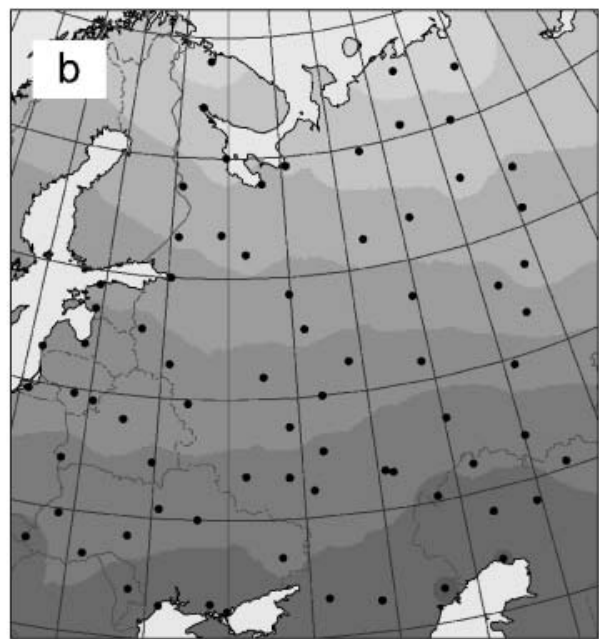

$\begin{array}{r}20-40 \\ 40-60 \\ 60-80\end{array} \quad \begin{array}{r}80-100 \\ 100-120 \\ 120-140\end{array} \mid \begin{array}{r}140-160 \\ \hline\end{array}$

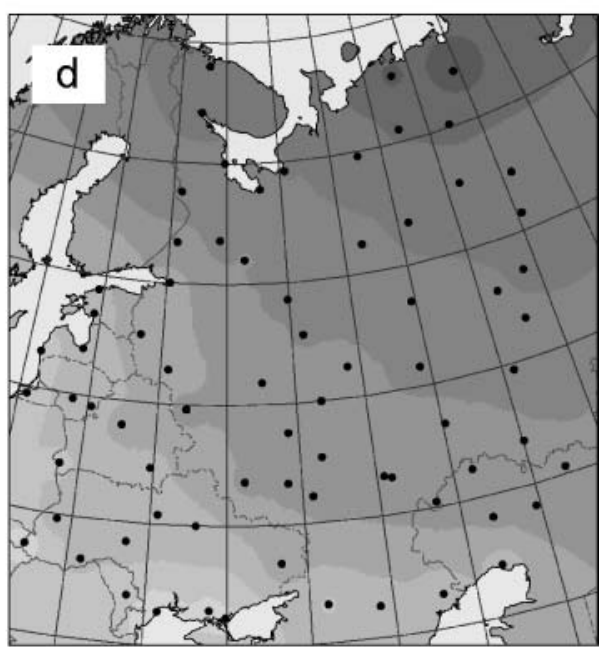

\begin{tabular}{|l|l|l|}
$\square$ & $50-70$ \\
$70-90$ & $110-130$ & $170-190$ \\
$70-110$ & $130-150$ & $190-210$ \\
90 & $150-170$ & $210-230$
\end{tabular}

Fig. 3. Mean duration of climatic seasons (73 stations, 1946-1995): (a) early spring, (b) summer, (c) autumn and (d) winter
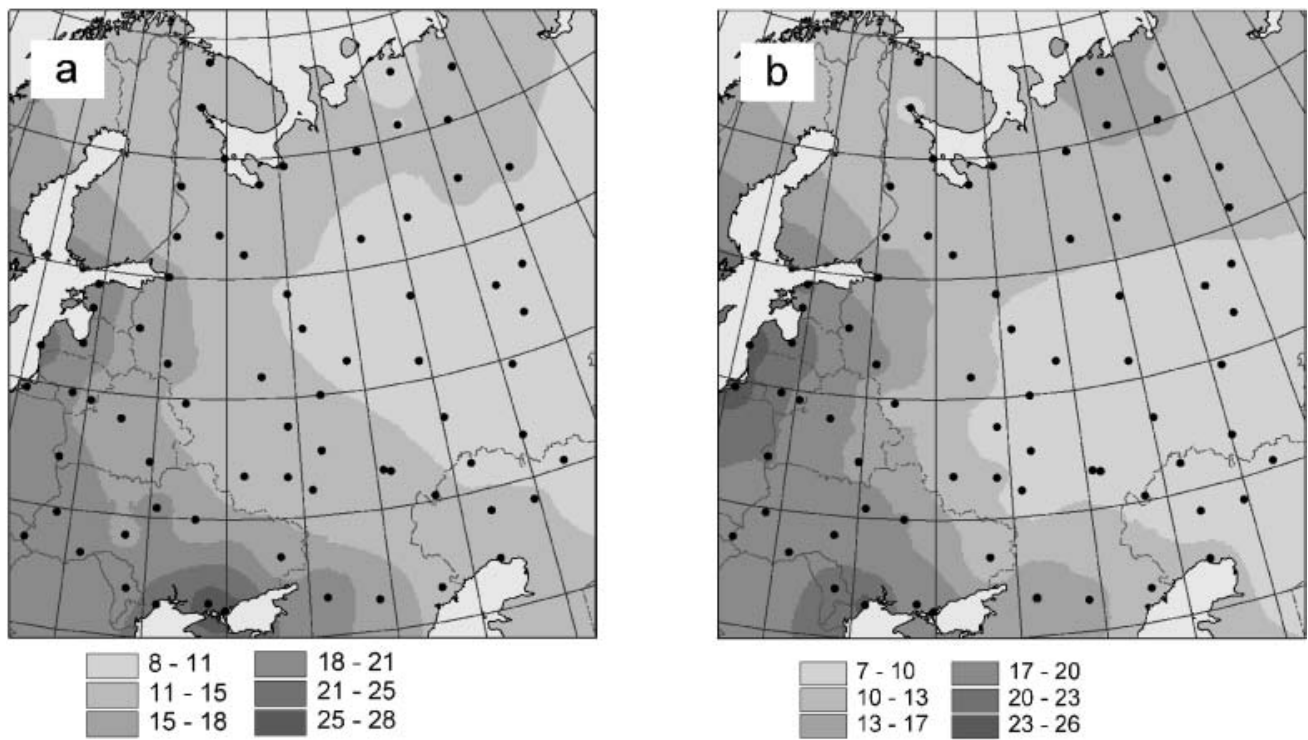

Fig. 4. Standard deviation of start date of climatic seasons (73 stations, 1946-1995): (a) winter and (b) early spring 

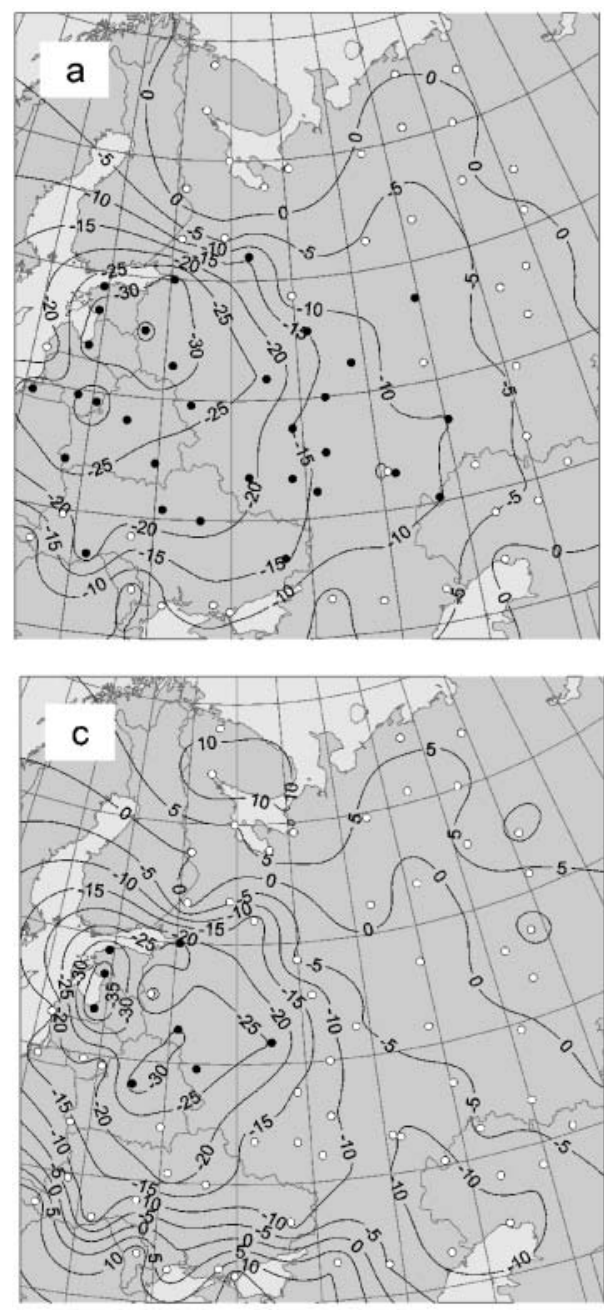

general, the duration of winter has decreased (Fig. 5c). This is explained by the earlier end of the winter season and start of early spring.

Statistical significance of these trends is different depending on the temporal variability of the studied variables. For example, in regions of low temporal variability, first of all in the eastern part of the East European Plain, the change of $10 \mathrm{~d}$ during the half-century is significant at the $p<0.05$ level. At the same time, in regions of high temporal variability (the Baltic region, Ukraine), a change of even $15 \mathrm{~d}$ is not statistically significant.

\subsection{Long period (1881-1995)}

The long time series of start date and duration of climatic seasons enables the analysis of centennial trends. Changes in climatic seasons in 12 stations (Fig. 1) during the long period (1881-1995) are presented in Tables 3 \& 4. Results of regression analysis demonstrate a signifi-

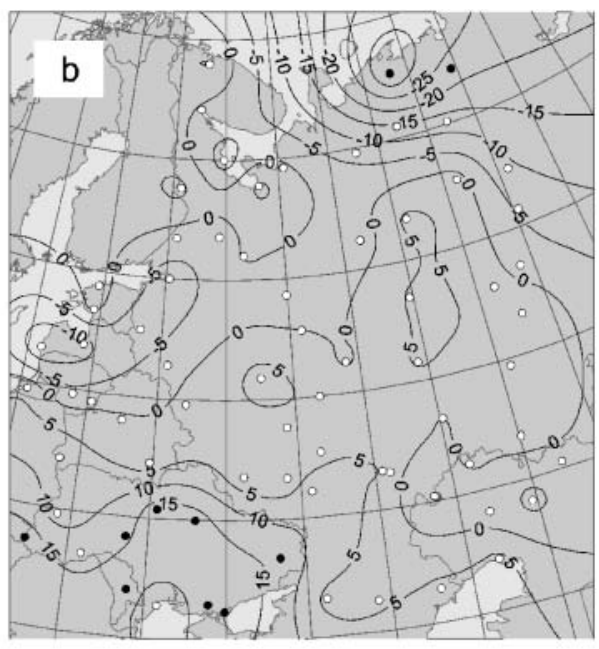

Fig. 5. Change in days by linear trend during the period 1946-1995: (a) start date of early spring, (b) duration of spring and (c) duration of winter. Stations with significant trend at $\mathrm{p}<0.05$ level are marked using black spots

cant shift in the start dates of early spring and spring to an earlier time. Warmer springs can be explained as a manifestation of global warming in the East European Plain. Earlier onset of summer is observed only on the Caspian lowland. No trends were detected for start dates of autumn, late autumn and winter.

Duration of 2 climatic seasons has changed significantly during the long period at some stations in the East European Plain. Duration of spring has increased and duration of winter has decreased by approximately 1 to 2 wk (Table 4 ). St. Petersburg is characterised by the most remarkable trends (Fig. 6). Early spring has a tendency to start much earlier. Therefore, the duration of winter has decreased by exactly $1 \mathrm{mo}$, following a linear trend.

\section{REGIONALISATION BY CLIMATIC SEASONS}

The East European Plain is divided into regions with similar fluctuations using cluster analysis and PCA. 
Table 3. Changes by trend in start date of climatic seasons during the long period 1881-1995. Positive change indicates a move to a later time and vice versa. Statistically significant changes at the $\mathrm{p}<0.05$ level are shown in bold

\begin{tabular}{|c|c|c|c|c|c|c|}
\hline & $\begin{array}{l}\text { Early } \\
\text { spring }\end{array}$ & Spring & Summer & Autumn & $\begin{array}{c}\text { Late } \\
\text { autumn }\end{array}$ & Winter \\
\hline Arkhangel'sk & -3.2 & -3.2 & -5.1 & -1.7 & -1.9 & 6.0 \\
\hline Astrahan' & -4.1 & -9.1 & -9.3 & -1.8 & -2.5 & 1.9 \\
\hline Elat'ma ${ }^{a}$ & -6.6 & -6.2 & 4.6 & 1.3 & 0.1 & 3.0 \\
\hline Gur'jev & -5.8 & -9.0 & -10.5 & -2.5 & -0.3 & 7.0 \\
\hline Kazan' & -3.4 & -5.4 & 1.7 & -1.9 & 0.6 & -3.3 \\
\hline Kiev & -10.1 & -12.0 & -1.5 & -0.3 & 6.6 & 7.9 \\
\hline Kirov & -8.8 & -9.0 & 2.9 & 0.9 & -1.2 & 3.3 \\
\hline Nižnij Novgorod & -6.9 & -3.1 & 2.1 & -2.8 & 1.8 & -1.5 \\
\hline Oktjabr'skij Gorodok & -8.5 & -7.9 & 1.3 & -0.4 & 2.7 & 1.3 \\
\hline Orenburg & -8.7 & -8.9 & -4.9 & 0.6 & 4.8 & 0.4 \\
\hline Perm' & -6.0 & -7.3 & 7.7 & 0.8 & 0.1 & 0.9 \\
\hline St. Petersburg & -25.4 & -9.6 & -7.9 & 1.0 & 6.2 & 4.8 \\
\hline${ }^{\mathrm{a}}$ First year was 1886 & & & & & & \\
\hline
\end{tabular}

Table 4. Changes by trend in duration of climatic seasons during the long period 1881-1995. Statistically significant changes at the $p<0.05$ level are shown in bold

\begin{tabular}{|c|c|c|c|c|c|c|}
\hline & $\begin{array}{l}\text { Early } \\
\text { spring }\end{array}$ & Spring & Summer & Autumn & $\begin{array}{l}\text { Late } \\
\text { autumn }\end{array}$ & Winter \\
\hline Arkhangel'sk & 0.0 & -1.9 & 3.4 & -0.3 & 7.9 & -9.8 \\
\hline Astrahan' & -5.0 & -0.2 & 7.5 & -0.7 & 4.4 & -6.0 \\
\hline Elat'ma ${ }^{a}$ & 0.5 & 10.8 & -3.3 & -1.2 & 3.0 & -10.3 \\
\hline Gur'jev & -3.2 & -1.4 & 8.0 & 2.2 & 7.3 & -12.6 \\
\hline Kazan' & -2.0 & 7.1 & -3.6 & 2.5 & -3.8 & -0.3 \\
\hline Kiev & -1.9 & 10.4 & 1.3 & 6.9 & 1.2 & -18.0 \\
\hline Kirov & -0.1 & 11.9 & -2.0 & -2.1 & 4.5 & -11.6 \\
\hline Nižnij Novgorod & 3.8 & 5.2 & -4.8 & 4.5 & -3.3 & -4.9 \\
\hline Oktjabr'skij Gorodok & 0.6 & 9.1 & -1.6 & 3.1 & -1.5 & -9.4 \\
\hline Orenburg & -0.2 & 4.0 & 5.5 & 4.3 & -4.5 & -8.5 \\
\hline Perm' & -1.3 & 15.0 & -6.8 & -0.8 & 0.8 & -7.5 \\
\hline St. Petersburg & 15.9 & 1.6 & 8.9 & 5.3 & -1.4 & -30.6 \\
\hline${ }^{a}$ First year was 1886 & & & & & & \\
\hline
\end{tabular}

dates of climatic seasons in that region is very high, especially in early spring, summer and late autumn. The first PC of onset of spring has the highest correlation in the central and southern part of Russia, that of autumn in southern Russia and Kazakhstan, and that of winter in eastern part of European Russia.

Some other specific groups of stations can be separated. In northern Russia 2 different regions can be found. The western one includes Carelia, the Kola Peninsula and the White Sea area. Onset of summer in Murmansk, which lies under the influence of the cold Barents Sea and has its own rhythm of fluctuations, is the only exception. Another group of stations is located in the northeasternmost part.

Specific stations are also located in other peripheral regions of the East European Plain. Kaliningrad and Liepaja are situated in locations under the influence of the ice-free part of the Baltic Sea. Užgorod lies on the SW side of the Carpathian Mountains. Chisinau, Odessa, AskanijaNova, and Genièesk are influenced by the Black Sea. At all of these stations, the winter climate is remarkably milder than at other stations of the same latitude.

The summary regionalisation of the East European Plain by start dates of climatic seasons is presented in Fig. 8. It is based on the results of cluster analysis expressed as a tree diagram (Fig. 9).

Eigenvalues of the 10 first components of start dates of climatic seasons are presented in Table 5. The highest proportion of the first $\mathrm{PC}$ in the total variance is revealed for the start date of early spring (40\%) and the lowest proportion for summer $(24 \%)$. The proportion of the second $\mathrm{PC}$ is ca. $15 \%$, with a maximum in winter. The proportion of the third PC is the highest in summer. The first 10 PCs describe 80 to $85 \%$ of total variance.

The regionalisation schemes for start dates of single climatic seasons are presented in Fig. 7. Each selected region is numbered according to the number of the PC that has the highest correlation with the stations of that region. It can be seen that stations located in the Baltic region and in western Russia have the highest correlation with first 3 PCs. It means that variation in start
At first, 2 climatic zones are selected-SubArctic (3 northernmost stations) and Temperate (the rest of the stations). The Temperate Zone can be divided into 2 subzones: boreal in the northern and sub-boreal in the southern part of the East European Plain.

The results indicate that the highest correlation between start dates of climatic seasons is observed in the central and southern parts of the study area. Fluctuations in the northern parts are less coherent. Therefore, the sub-Arctic zone is divided into 2 regions - the coast of the Kola Peninsula (Murmansk) and tundra (Narjan-Mar, Hoseda-Hard); and the boreal sub-zone, into 3 regions - Carelia-White Sea, Pechora lowland, and northern Russia-Urals.

The sub-boreal sub-zone encompasses the majority of the territory and stations in the East European Plain. 


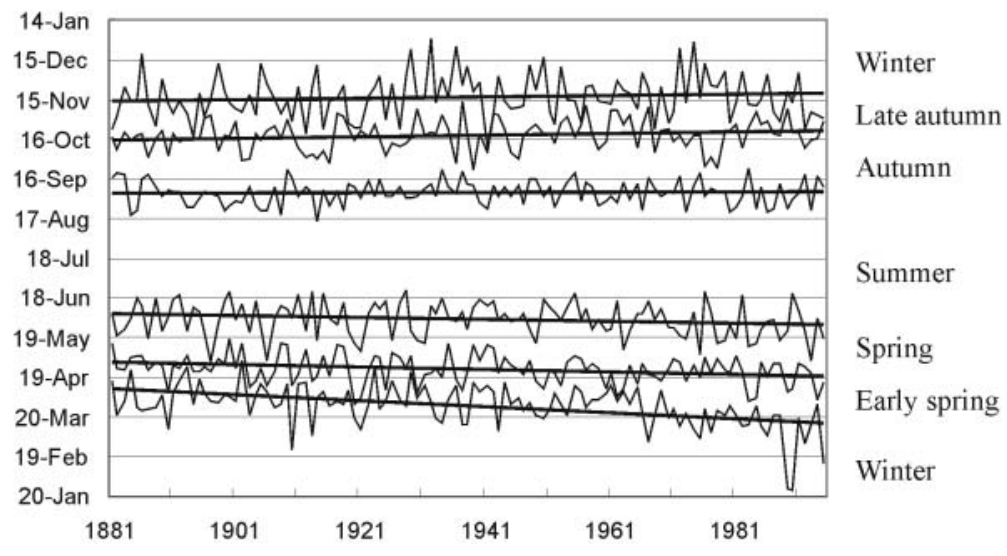

Fig. 6. Time series of start date of climatic seasons at St. Petersburg and their linear trends in 1881-1995

It is characterised by rather coherent variations in climatic seasons in time and is divided into only 2 regions. The western one, which embraces Estonia, Latvia, Lithuania, Belarus, the northern part of the Ukraine, and westernmost Russia (Kaliningrad, St. Petersburg, Pskov, Velikie Luki), lies under a much stronger Atlantic influence and has a more maritime climate. The continental region includes central and southern Russia, western Kazakhstan and southern Ukraine.

PCA of the pooled data set yielded 18 PCs with eigenvalues greater than 1 . The first 4 PCs described $83.8 \%$ of the pooled data-set variance. The first PC accounted for a very high percentage $(69.6 \%)$ of the variance compared to following PCs (second, third and fourth $8.7,3.0$ and $2.5 \%$, respectively). Therefore, this first PC represents the most dominant spatial pattern in the data set, running from north to south and affecting the whole of the East European Plain (Fig. 10a). The second PC depicts the east-western gradient over the study area (Fig. 10b). The next 2 components account for quite low percentages and represent strongly localised spatial patterns. The third PC emphasises the local differences between stations within the western part of the East European Plain (Fig. 10c). The fourth PC reflects local differences in the northeasternmost part (Fig. 10d).

\section{RELATIONSHIPS WITH ATMOSPHERIC CIRCULATION}

\subsection{Early spring}

Start date of early spring depends mostly on intensity of westerlies during the second half of winter. The higher the intensity of the zonal circulation, the earlier the end of winter and the start of early spring. Correspondingly, there is a significant negative correlation between start date of early spring and frequency of Circulation Form W, and NAO and AO indices in January, February and March, on most parts of the East European Plain. In some stations, correlation coefficients even exceed 0.6 (Fig. 11a).

The area of maximum correlation coincides with Region 1 on Fig. 7a. It means that the main influence of westerlies is expressed by the first PC, which has the highest correlation with start date of early spring in the western part of the study area. Correlation coefficient between time series of scores of the first PC and frequency of Circulation Form W, and $\mathrm{NAO}$ and $\mathrm{AO}$ indices in the second half of winter is 0.4 and 0.7. The other PCs have rather low correlation with zonal circulation. Table 6 represents all statistically significant correlation coefficients between time series of the 8 first PCs and monthly parameters of atmospheric circulation. However, it should be taken into account that PCs at different months embrace different regions, as presented in Fig. 7.

Meridional circulation, in contrast, is positively correlated with the start date of early spring. It is late in cases of high frequency of circulation Forms E and C. E has a significant positive correlation with the first $\mathrm{PC}$ in February and with the second PC in January and March (Table 6). Correlation coefficients are much lower than in the case of zonal circulation. The EW tele-connection index in April has a high positive correlation with the start date of early spring in northern Russia (Regions 2, 5, and 7). It means that northwesterly airflow is related to late start and southeasterly flow with early start of early spring.

Table 5. Cumulative eigenvalues obtained from PCA of the start dates of climatic seasons in 1946-1995

\begin{tabular}{|lcccccc|}
\hline PC & $\begin{array}{c}\text { Early } \\
\text { spring }\end{array}$ & Spring & Summer & Autumn & $\begin{array}{c}\text { Late } \\
\text { autumn }\end{array}$ & Winter \\
\hline 1 & 40.1 & 33.0 & 23.8 & 26.1 & 33.9 & 25.1 \\
2 & 54.0 & 45.1 & 38.3 & 41.9 & 48.2 & 44.3 \\
3 & 63.6 & 54.0 & 52.0 & 50.3 & 57.8 & 55.7 \\
4 & 70.2 & 61.6 & 58.4 & 57.2 & 63.9 & 64.0 \\
5 & 74.2 & 66.9 & 63.9 & 63.4 & 68.7 & 68.4 \\
6 & 76.8 & 70.4 & 68.8 & 68.3 & 72.4 & 72.4 \\
7 & 79.1 & 73.5 & 72.8 & 71.9 & 75.5 & 75.4 \\
8 & 81.4 & 76.5 & 75.6 & 75.0 & 78.3 & 78.2 \\
9 & 83.3 & 79.0 & 78.0 & 77.5 & 80.7 & 80.8 \\
10 & 85.0 & 81.2 & 79.9 & 79.8 & 82.5 & 82.8 \\
& & & & & & \\
\hline
\end{tabular}



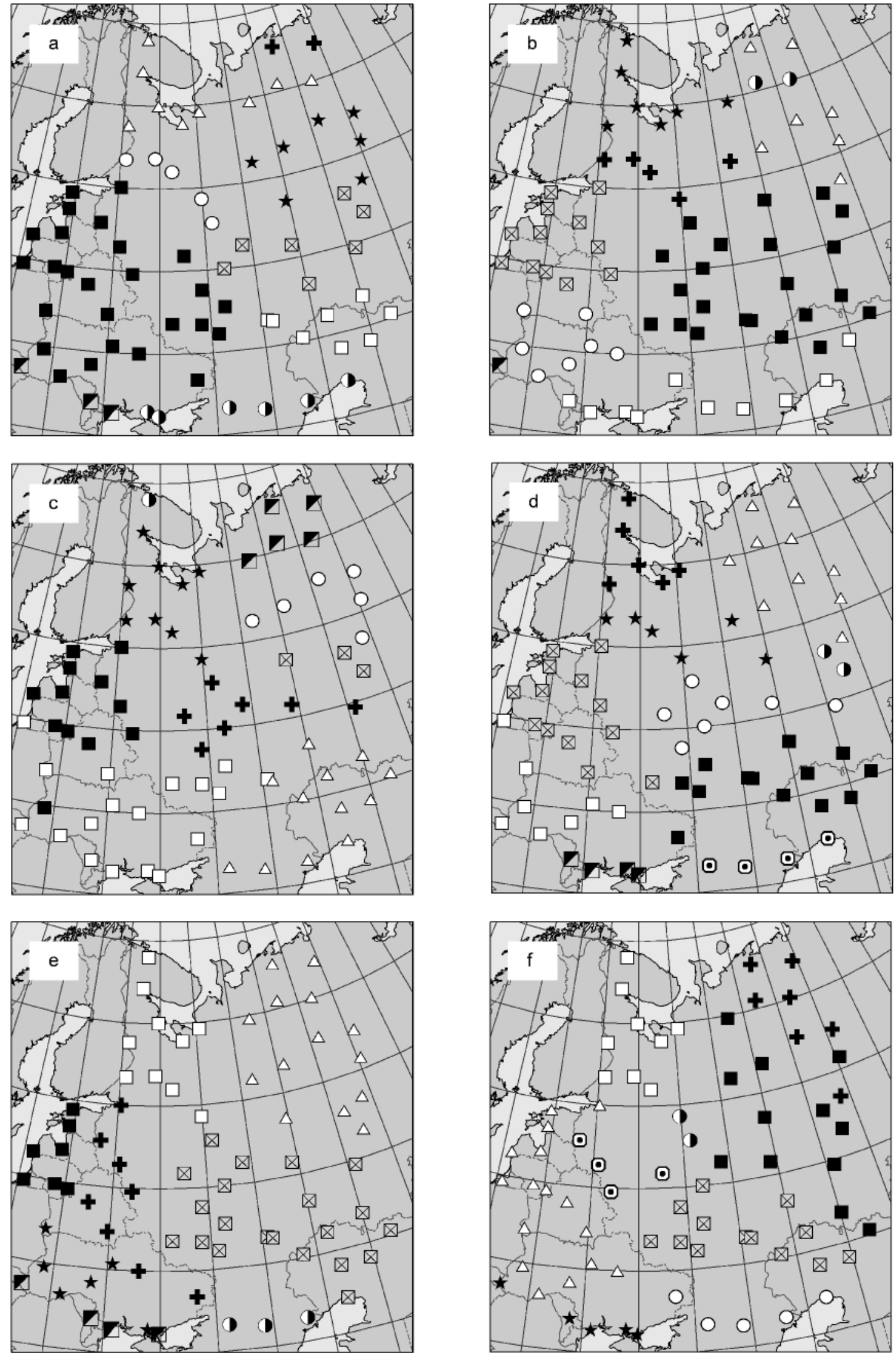

Fig. 7. Regionalisation of stations by PCA: (a) early spring, (b) spring, (c) summer, (d) autumn, (e) late autumn and (f) winter. Regions are indicated as follows: $\mathbf{\square}, 1 ; \Delta, 2 ; \boldsymbol{\nabla}, 3 ; \square, 4 ; \star, 5 ; 0,6 ; \mathbf{4}, 7 ; \boldsymbol{\nabla}, 8 ; \boldsymbol{\square}, 9 ; 0,10$ 


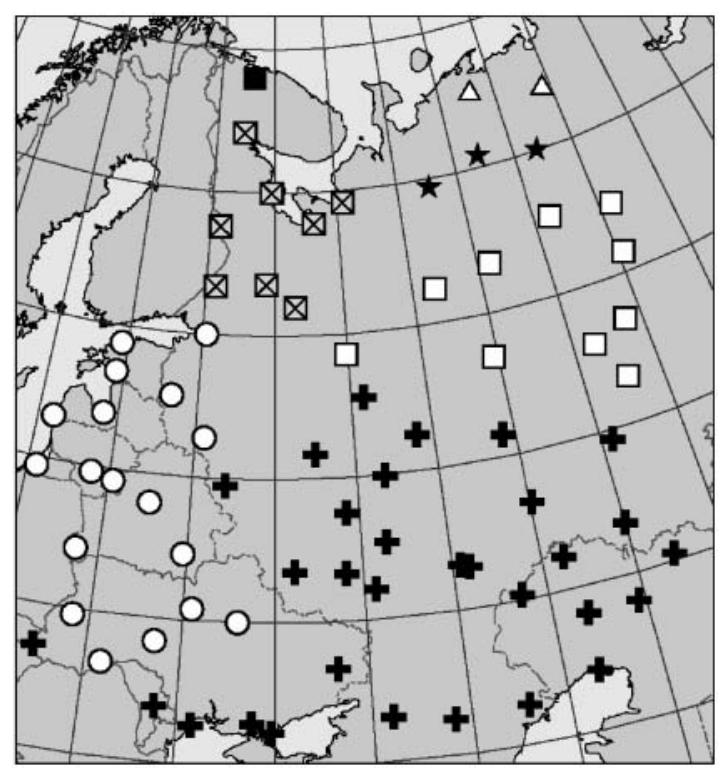

Fig. 8. Summary regionalisation of the East European Plain by start dates of climatic seasons. For meaning of symbols, see Fig. 7

Start date and duration of early spring are highly correlated. An earlier start corresponds to a longer duration, and vice versa. Duration of early spring in the western part of the East European Plain is positively correlated with characteristics of zonal circulation and negatively correlated with meridional circulation in February and March.

\subsection{Spring}

The influence of atmospheric circulation on the start date of spring is weaker than in the previous climatic season. Results of correlation analysis indicate a residual effect of winter. For example, the start date of spring has a significant negative correlation with zonal circulation and a high positive correlation with frequency of Circulation Form E during the proceeding winter months. After a mild winter caused by intensive zonal circulation, an early onset of spring is usually observed. This effect is observed in its strongest form in the western and northern parts of the study area (Regions 3, 5, and 6; Fig. 7b, Table 6).

In April, when the spring season usually starts in the East European Plain, not zonal but meridional circulation plays the main role. While, in winter, Circulation Form E has a positive correlation with the start date of spring, in April its sign changes. Southeasterly airflow brings hot air from arid regions of Central Asia that accelerates the onset of spring. The warming effect of Circulation Form $\mathrm{E}$ is most remarkable in northern
Russia (Region 5) in May. The fifth PC is also negatively correlated with the SC tele-connection index in spring $(r=0.45)$ that expresses a similar dependence.

Start date of spring has the highest correlation with frequency of Circulation Form C (Arctic airflow) in April in the whole European territory of Russia except in its northern parts (Fig. 11b). Correlation coefficient of frequency of the Form $\mathrm{C}$ in April with time series of scores of the first PC is 0.42 (Table 6). The first PC of the start dates of spring (Region 1; Fig. 7b) has the highest correlation with EW tele-connection index in April ( $\mathrm{r}=$ 0.68). It also represents meridional circulation.

Duration of spring is less influenced by atmospheric circulation. There are only some significant correlations. Circulation Forms C in May and W in June are positively correlated, and E in May is negatively correlated with duration of spring in Region 3. In the case of southerly circulation (E), spring ends and summer starts earlier, in May, while in the case of northerly circulation (C) spring is colder and continues until June. When weather conditions in June are under the influence of westerlies, Atlantic air, and cyclones (W), then the start of the summer season is moved to the second half of the month and the duration of spring reaches its maximum. A high frequency of the Circulation Form $\mathrm{C}$ in June is related to long springs in northern Russia.

\subsection{Summer}

Start date of the summer season has significant correlations with frequency of circulation forms (according to Vangengeim 1952 and Girs 1971) and with teleconnection indices, but not with NAO indices. Due to different start dates at different latitudes, the influence of atmospheric circulation is revealed for different months. Westerly Circulation Form W in May and June has a significant positive correlation with start date of summer in Region 1 (Fig. 7c), i.e. with the first PC (Table 6). The same effect is connected with the EJ index, which has the highest correlation in May ( $\mathrm{r}=$ 0.59).

Southerly and easterly circulation (Form E) is connected with an earlier start of summer. A high negative correlation is determined for May in the central and western part of the East European Plain (Fig. 11c), for PCs 1 and 7. The same correlation in southern Russia (PC 2) is evident in April, and in northern Russia (PC 5) in June. The highest values of correlation coefficient are up to 0.5 . Circulation Form $\mathrm{C}$ has a significant positive correlation with the start date of summer in southern latitudes (PC 2) in April, in central latitudes (PC 7) in May, and in the northern part (PC 5) in June.

As in the case of spring, EW index also has a significant positive correlation with the start date of summer 


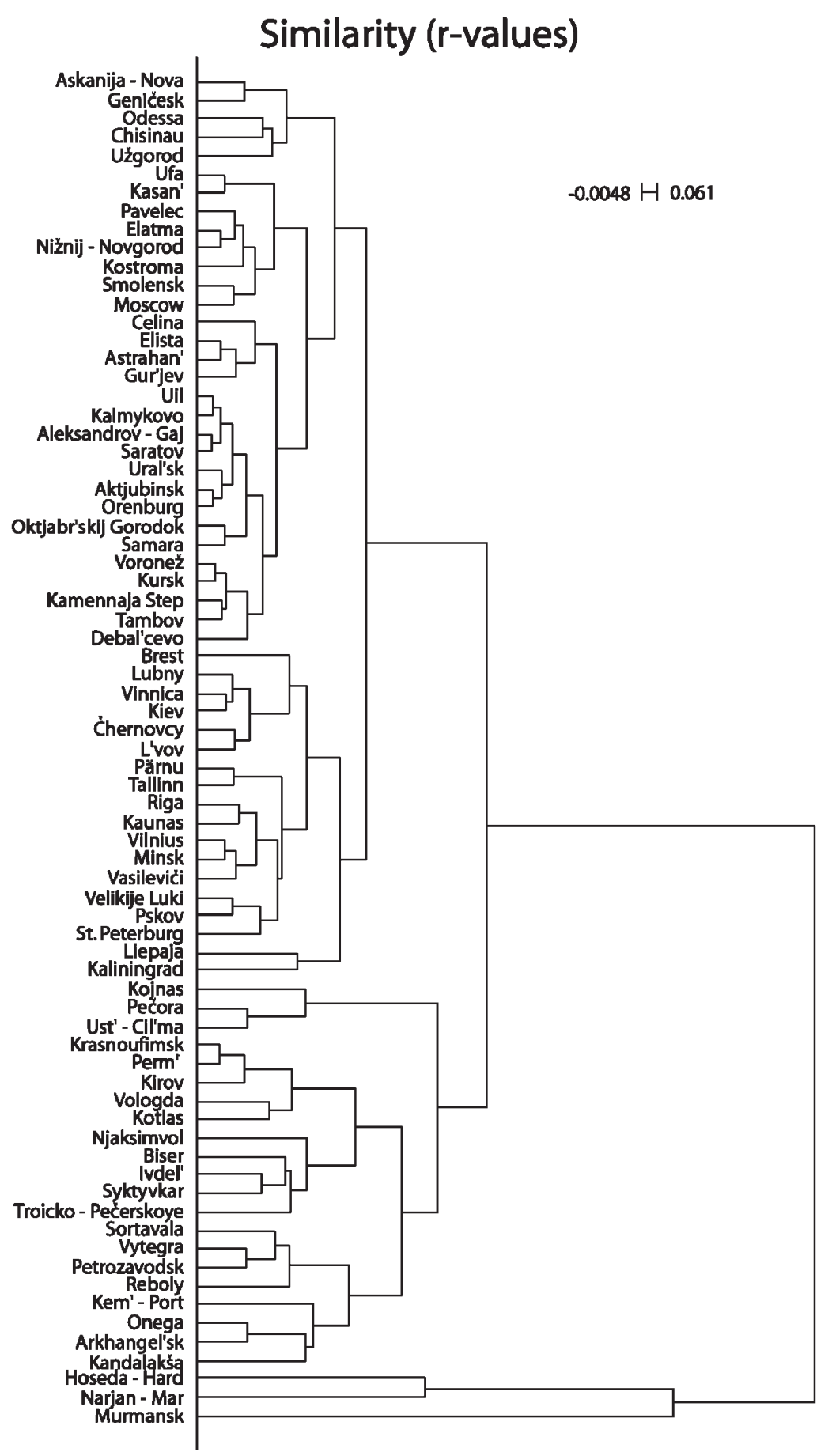

Fig. 9. Tree diagram for the summary regionalisation of the East European Plain by start dates of climatic seasons

the northernmost stations, where, in July, the prevalence of Circulation Form E increases its duration, and $\mathrm{C}$ decreases it. In August and September, Form E also lengthens summer in many stations all over the East European Plain.

\subsection{Autumn}

The end of summer and start of autumn is related to atmospheric circulation conditions mostly in July, August and September. And, circulation conditions in July influence only the northernmost stations. Frequency of Circulation Form W, as well as NAO, AO, and EJ indices, are negatively correlated with start date of autumn, i.e. intense westerlies cause an earlier start of autumn. The highest correlation is observed with circulation in August (Fig. 11d).

Prevalence of Circulation Form E (southeasterly airflow) is connected with the late start of autumn (Table 6). Significant positive correlation in July exists in northern Russia (Regions 2 and 7; Fig. 7d), in August in northern and central Russia (Region 5), and in September in the Baltic States, Belarus, and central Russia (Regions 3 and 6). Form $C_{\text {, representing }}$ northerly circulation, has a negative relationship in July with the start date of autumn in the north (Region 7) and in September with the start date of autumn in central Russia (Region 6).

Tele-connection indices have a number of statistically significant correlations with the start date of autumn. The East Atlantic index has a positive correlation in September in the western part of the study area, in Regions 3 and 4. In this case, the EA index describes southeasterly-northwesterly circulation. Of course, southeasterly winds lead to warmer weather and later onset of autumn. Positive values of EW indices are followed by an earlier start of autumn in southern Russia and western Kazakhstan (Regions 1, 6, and 9). The Scandinavian tele-connection index is positively corre-

in southern Russia and Kazakhstan. Correlation coefficients are remarkable-0.56 in Region 2 in April and 0.53 in Region 7 in May. EW index is the leading parameter of meridional circulation in the study area.

Duration of the summer season is not very much influenced by circulation. It is most pronounced only in lated in August with the start date of autumn in northern Russia (Regions 2 and 5; Fig. 7d).

Duration of the autumn season has the highest correlation with frequency of circulation forms, according to Vangengeim (1952) and Girs (1971). Prevalence of the Circulation Form W in August (in the NW Regions - 3, 

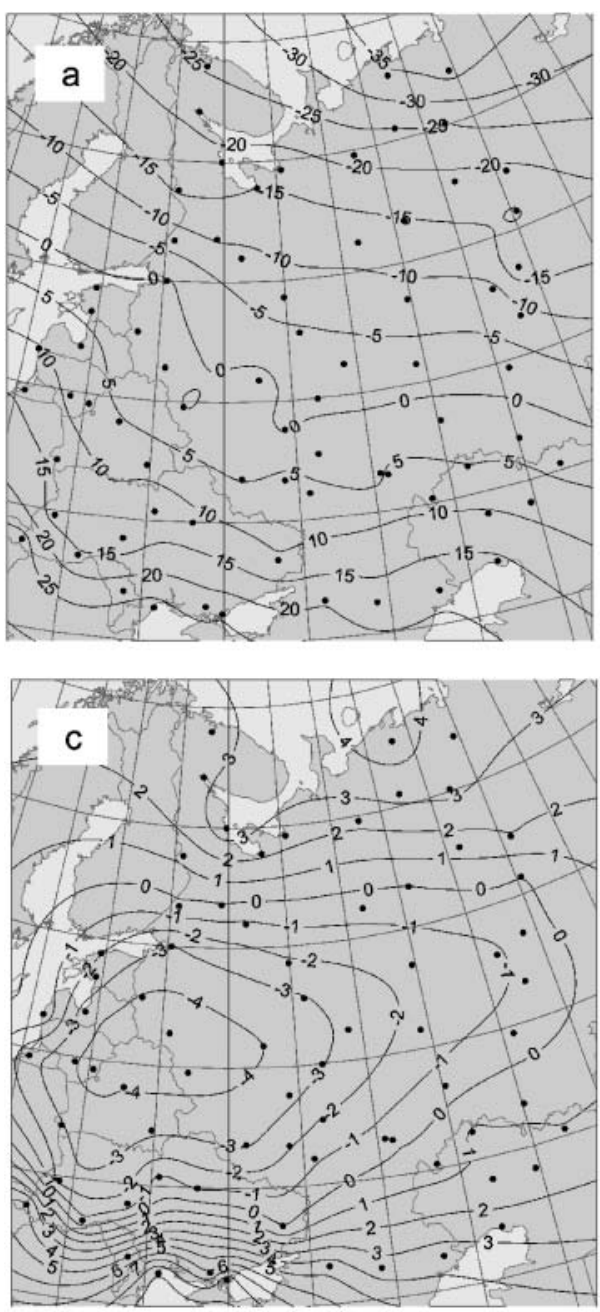
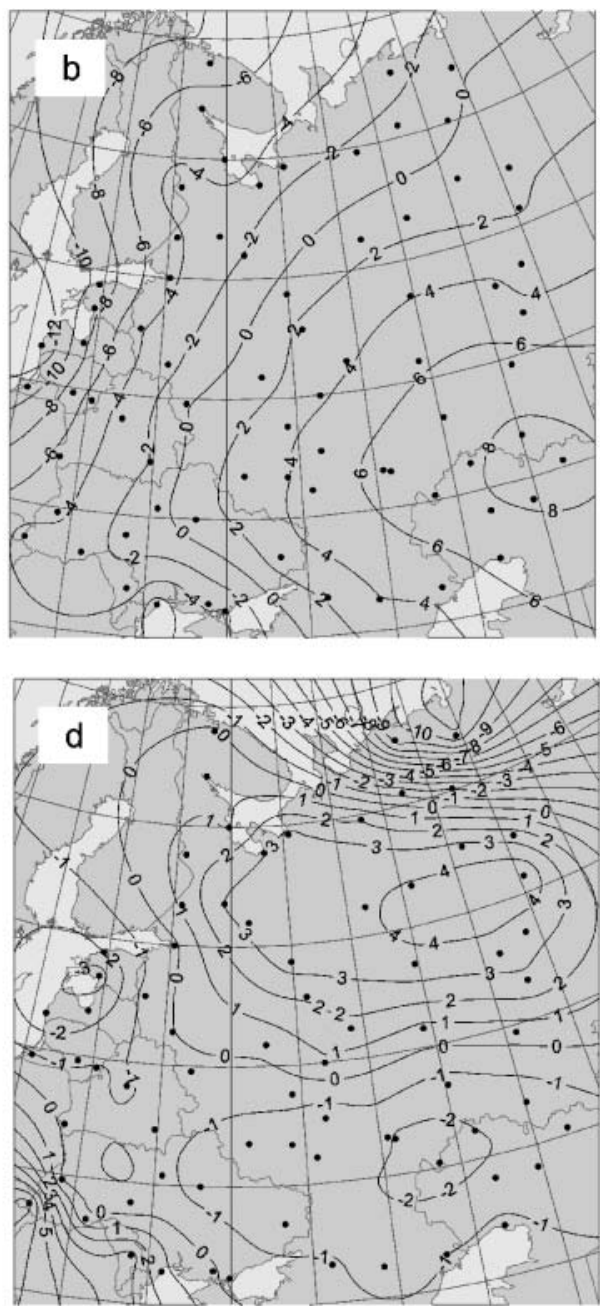

Fig. 10. Principal components (PC) of start dates of climatic seasons: (a) PC 1, (b) PC 2, (c) PC 3, (d) PC 4

5, and 7), in September (in the northeast-Region 2) and in October (in the southeast-Regions 1 and 10) is followed by a long autumn. Form E (in July in Region 7, in August partly in Regions 3 and 5, and in September in Regions 3 and 6) causes short autumns. Form C has different relationships with the duration of autumn. In September, it is negatively correlated in the north (Region 2) and positively correlated in the south (Regions 1, 6, and 10).

\subsection{Late autumn}

The start of late autumn occurs mostly in October, spanning on average from late September in the northeast to the first half of November in the southwest. In general, westerly circulation is related to late start of late autumn and northerly circulation to early start. The area of the highest correlation is located in differ- ent regions (Table 6). When, in September, correlation is the highest in northern Russia (Regions 2 and 4; Fig. 11e), then, in October, it is highest in the Baltic Sea area and Belarus (Regions 1 and 7). The maximum correlation of NAO index (Gibraltar) was revealed with the first PC in October-0.61.

Northern circulation is characterised by frequency of Circulation Form $\mathrm{C}$ and the EW tele-connection index. In October, Form $\mathrm{C}$ has a significantly negative correlation with start date of late autumn in Regions 7 and 9, while the EW index has a high correlation $(\mathrm{r}=-0.55)$ with the second PC (the NE part of the study area).

Duration of late autumn is less influenced by atmospheric circulation. Relationships in different regions are of opposite sign. For example, Circulation Form W has a significant positive correlation in some stations in northern Russia, but an even higher negative correlation in Belarus, the Ukraine, and the Caspian Sea region. In October, Form E is positively correlated with 

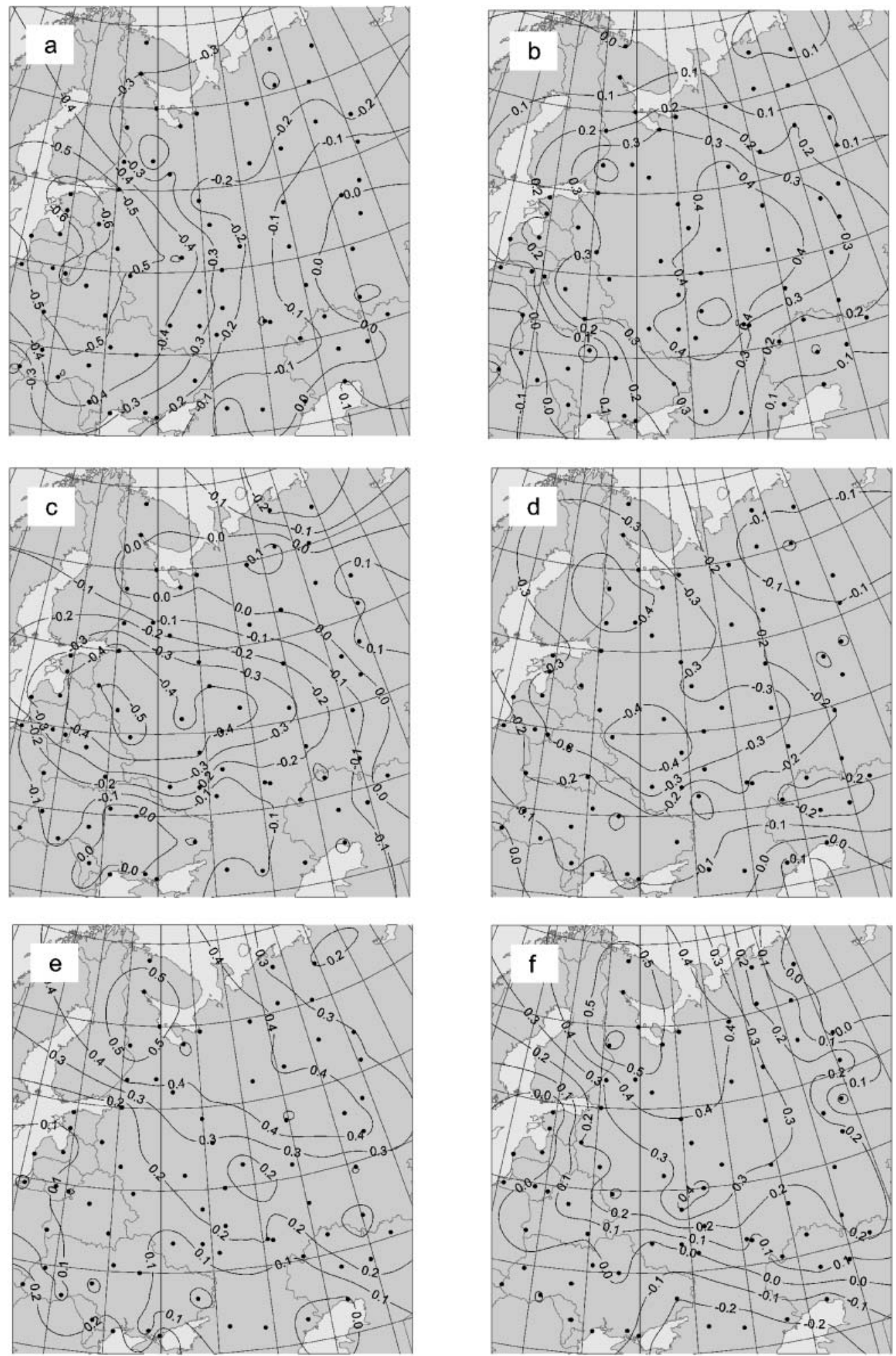

Fig. 11. Correlation map. (a) AO index in February and start date of early spring, (b) frequency of Circulation Form C in April and start date of spring, (c) frequency of Circulation Form E in April and start date of summer, (d) frequency of Circulation Form W and start of autumn, (e) NAO index (Ponta Delgada) in September and start of late autumn, and (f) NAO index (Ponta Delgada) 
Table 6. The statistically significant correlation coefficients between the 8 first PCs of start date of climatic seasons (for locations see Fig. 7) and monthly parameters of atmospheric circulation in 1946-1995 (tele-connection indices in 1950-1995). Correlation at the $\mathrm{p}<0.005$ level are marked in bold. W, E, C-frequencies of circulation Forms W, E and C, respectively; indexes: NP-North Atlantic oscillation (Ponta Delgada), NG-North Atlantic Oscillation (Gibraltar), AO-Arctic Oscillation; tele-connection indexes: NT-North Atlantic Oscillation, EA-East Atlantic, EJ-East Atlantic Jet, EW-East Atlantic/West Russia, PL-Polar/Eurasia, SC-Scandinavia, AS-Asian summer

\begin{tabular}{|c|c|c|c|c|c|c|}
\hline $\mathrm{PC}$ & Early spring & Spring & Summer & Autumn & Late autumn & Winter \\
\hline 1 & $\begin{array}{l}\text { W II -0.62 } \\
\text { W III -0.40 } \\
\text { E II } \mathbf{0 . 4 1} \\
\text { C III } 0.30 \\
\text { NP I -0.28 } \\
\text { NP II -0.58} \\
\text { NP III }-\mathbf{0 . 5 4} \\
\text { NG I } \mathbf{- 0 . 4 0} \\
\text { NG II -0.61 } \\
\text { NG III -0.47 } \\
\text { AO I -0.33 } \\
\text { AO II }-\mathbf{0 . 6 3} \\
\text { AO III -0.52 } \\
\text { NT II -0.32 } \\
\text { NT III }-\mathbf{0 . 5 7} \\
\text { EA I -0.33 } \\
\text { EA II -0.36 } \\
\text { PE II }-\mathbf{0 . 5 2}\end{array}$ & $\begin{array}{l}\text { C IV } \mathbf{0 . 4 2} \\
\text { EW IV } \mathbf{0 . 6 8}\end{array}$ & $\begin{array}{l}\text { W V } 0.33 \\
\text { W VI } 0.32 \\
\text { E V -0.45 } \\
\text { NG IV } 0.33 \\
\text { NG VI } 0.38 \\
\text { AO IV } 0.31 \\
\text { NT IV } 0.37 \\
\text { EJ V } \mathbf{0 . 5 9} \\
\text { EJ VI } 0.30 \\
\text { SC V } 0.39\end{array}$ & EW IX -0.46 & $\begin{array}{l}\text { NP X } 0.52 \\
\text { NG X } 0.61 \\
\text { AO X } 0.43 \\
\text { NT X } 0.48\end{array}$ & $\begin{array}{l}\text { W X } \mathbf{0 . 4 4} \\
\text { C X }-0.39 \\
\text { EW XI } 0.31\end{array}$ \\
\hline 2 & $\begin{array}{l}\text { W I }-0.35 \\
\text { E I } 0.34 \\
\text { E III } 0.29 \\
\text { C III }-0.37 \\
\text { AO II }-0.29 \\
\text { AO IV }-0.31 \\
\text { NT II }-0.32 \\
\text { EA IV } 0.32 \\
\text { EW IV } \mathbf{0 . 6 8}\end{array}$ & $\begin{array}{l}\text { E I } 0.28 \\
\text { EA IV } 0.37 \\
\text { PE II } 0.30 \\
\text { EW IV } 0.40 \\
\text { SC IV } 0.38\end{array}$ & $\begin{array}{l}\text { E IV }-0.28 \\
\text { C IV } \mathbf{0 . 4 0} \\
\text { NT IV } 0.36 \\
\text { EW IV } \mathbf{0 . 5 6}\end{array}$ & $\begin{array}{l}\text { W IX }-0.29 \\
\text { E VII } 0.33 \\
\text { C IX } 0.28 \\
\text { NP IX }-0.30 \\
\text { NG IX }-0.32 \\
\text { AO IX }-0.28 \\
\text { NT IX }-0.32 \\
\text { SC VIII } 0.34\end{array}$ & $\begin{array}{l}\text { C IX }-0.29 \\
\text { NP IX } 0.30 \\
\text { EW IX }-\mathbf{0 . 5 5}\end{array}$ & $\begin{array}{l}\text { E X } 0.36 \\
\text { C XI -0.43 } \\
\text { NP XI } 0.37 \\
\text { NG XI } \mathbf{0 . 4 5} \\
\text { AO X }-0.30\end{array}$ \\
\hline 3 & $\begin{array}{l}\text { NP I }-0.35 \\
\text { NG I }-0.30 \\
\text { NT I }-0.32\end{array}$ & $\begin{array}{l}\text { E III } \mathbf{0 . 4 5} \\
\text { C III }-0.32 \\
\text { NG I }-0.28 \\
\text { AO II }-0.28 \\
\text { NT I }-0.36\end{array}$ & $\begin{array}{l}\text { NP III } 0.28 \\
\text { NG III } 0.29 \\
\text { AO III } 0.34 \\
\text { NT V }-0.31\end{array}$ & $\begin{array}{l}\text { E IX } 0.29 \\
\text { AO VIII } 0.30 \\
\text { NT VIII } 0.29 \\
\text { NT IX } 0.36 \\
\text { EA IX } 0.33 \\
\text { EJ VIII }-0.33 \\
\text { AS VII }-\mathbf{0 . 4 1} \\
\text { AS VIII }-0.31\end{array}$ & & $\begin{array}{l}\text { W XI } 0.30 \\
\text { E X }-0.36 \\
\text { AO X } 0.33 \\
\text { NT IX } 0.29\end{array}$ \\
\hline 4 & $\begin{array}{l}\text { E I }-0.29 \\
\text { EW I } 0.30\end{array}$ & $\begin{array}{l}\text { W III }-0.34 \\
\text { C II } 0.30 \\
\text { EA I }-0.30 \\
\text { EA II }-0.37 \\
\text { SC III } 0.41\end{array}$ & E III 0.30 & EA IX $\mathbf{0 . 5 0}$ & $\begin{array}{l}\text { E X } 0.31 \\
\text { NP IX } \mathbf{0 . 4 2} \\
\text { EA IX } \mathbf{0 . 4 1}\end{array}$ & $\begin{array}{l}\text { NP X } \mathbf{0 . 5 8} \\
\text { NG X } \mathbf{0 . 4 5} \\
\text { AO IX } 0.31 \\
\text { AO X } \mathbf{0 . 4 9} \\
\text { NT XI } 0.33\end{array}$ \\
\hline 5 & EW IV -0.49 & $\begin{array}{l}\text { E II } 0.30 \\
\text { E V -0.45 } \\
\text { C V } 0.32 \\
\text { NP III }-0.30 \\
\text { NG III -0.34 } \\
\text { AO II }-0.37 \\
\text { AO III -0.28 } \\
\text { NT V }-\mathbf{0 . 4 2} \\
\text { EA III -0.33 } \\
\text { PL II }-0.38\end{array}$ & $\begin{array}{l}\text { E VI -0.42 } \\
\text { C VI } \mathbf{0 . 4 2} \\
\text { NP IV } 0.31 \\
\text { NP VI }-0.34 \\
\text { AO IV } 0.36 \\
\text { AO VI }-\mathbf{0 . 4 3}\end{array}$ & $\begin{array}{l}\text { W VIII }-0.28 \\
\text { E VIII } 0.44 \\
\text { NP VIII } 0.34 \\
\text { NG VIII } 0.33 \\
\text { SC VIII } 0.34\end{array}$ & NT IX 0.29 & $\begin{array}{l}\text { E XII } 0.29 \\
\text { C XII } \mathbf{- 0 . 4 1} \\
\text { NP IX } 0.29 \\
\text { AO XI }-0.34 \\
\text { NT XII } 0.29 \\
\text { EA IX } 0.39\end{array}$ \\
\hline
\end{tabular}


Table 6 (continued)

\begin{tabular}{|c|c|c|c|c|c|c|}
\hline PC & Early spring & Spring & Summer & Autumn & Late autumn & Winter \\
\hline 6 & $\begin{array}{l}\text { C IV } 0.34 \\
\text { NG I } 0.28 \\
\text { AO I } 0.38\end{array}$ & $\begin{array}{l}\text { W IV }-0.28 \\
\text { E IV } 0.34 \\
\text { NP I }-0.36 \\
\text { NP II }-0.35 \\
\text { NG I -0.40 } \\
\text { NG II }-0.30 \\
\text { AO I }-0.36 \\
\text { AO III -0.42 } \\
\text { NT II }-0.31 \\
\text { NT III }-0.38 \\
\text { EA I }-0.30 \\
\text { PE I }-0.31 \\
\text { PE II }-0.35 \\
\text { EW I }-0.30\end{array}$ & $\begin{array}{l}\text { E III } 0.29 \\
\text { C III }-0.32 \\
\text { NT VI } 0.35 \\
\text { EJ VI }-0.33 \\
\text { EW IV } 0.31\end{array}$ & $\begin{array}{l}\text { E IX } 0.37 \\
\text { C IX }-0.28 \\
\text { EW IX } \mathbf{- 0 . 5 4}\end{array}$ & & \\
\hline 7 & & C IV 0.31 & $\begin{array}{l}\text { W IV } 0.31 \\
\text { E V }-0.35 \\
\text { C V } 0.35 \\
\text { EW V } \mathbf{0 . 5 3}\end{array}$ & $\begin{array}{l}\text { E VII } 0.30 \\
\text { C VII }-0.35 \\
\text { NP VII } 0.35\end{array}$ & $\begin{array}{l}\text { W VIII } 0.32 \\
\text { W X } \mathbf{0 . 4 0} \\
\text { E VIII -0.31 } \\
\text { C X -0.40 } \\
\text { EJ VIII } 0.31\end{array}$ & $\begin{array}{l}\text { NP VIII } 0.30 \\
\text { NP IX } 0.34 \\
\text { AO IX } 0.29 \\
\text { EA IX } 0.43\end{array}$ \\
\hline 8 & EW II 0.32 & & $\begin{array}{l}\text { AO II }-0.28 \\
\text { EJ VI }-0.30\end{array}$ & $\begin{array}{l}\text { NP X }-0.31 \\
\text { NG X }-0.35\end{array}$ & $\begin{array}{l}\text { E XI } 0.31 \\
\text { C XI }-0.36 \\
\text { AO VIII -0.43 } \\
\text { NT VIII }-0.39 \\
\text { EW XI }-0.39 \\
\text { AS VIII }-0.30\end{array}$ & \\
\hline
\end{tabular}

the duration of late autumn in the Baltic Sea area and in the Ukraine, while being negatively correlated in southern Russia and western Kazakhstan. In September, Form C makes late autumn longer in northern Russia, and, in October, in southern Russia. In November it shortens late autumn in the Baltic region, causing an early start of winter.

\subsection{Winter}

Start date of winter in the northern part of the East European Plain is strongly determined by the intensity of westerlies in October (Fig. 11f). A high positive correlation between them means that the more intense the zonal circulation the later the start of winter. The frequency of Circulation Form $\mathrm{W}$ and the indices of zonal circulation (NP, NG, AO, NT, EA; Table 6) have a significant positive correlation with the start date of winter. Area of maximum correlation is situated in northern and central Russia (Regions 2, 4, 9 and 10). The meridional Circulation Form $\mathrm{C}$ in October and November causes an earlier start of winter in many regions.

Duration of winter depends on start date as well as on end date of the season. As a rule, prevalence of zonal circulation makes winter shorter, and that of meridional circulation makes it longer.

\section{DISCUSSION AND CONCLUSIONS}

\subsection{Spatio-temporal variability}

Spatial variability of start date and duration of climatic seasons in the East European Plain is very high. First of all, it is determined by the wide latitudinal extent of the study area-from 46 to $69^{\circ} \mathrm{N}$. Early spring, spring, and summer begin first in the south; and autumn, late autumn, and winter start first in the north. Spatial range of start date of climatic seasons is 2 to $3 \mathrm{mo}$, with a maximum in early spring. Correspondingly, duration of summer is longest in the southern Ukraine-more than $150 \mathrm{~d}$-and shortest on the coast of the Arctic Ocean-less than $30 \mathrm{~d}$. The winter season is longest in the NE corner (more than $220 \mathrm{~d}$ ) and shortest on the northern coast of the Black Sea (less than $60 \mathrm{~d}$ ).

The increasing continentality of the climate from west to east is the second factor determining climatic seasons over the East European Plain. Its influence is most marked in the start dates of climatic seasons dur- 
ing the cold half-year. Isolines of start date of late autumn, winter, and early spring are oriented not so much in a west-east, but more in a northwest-southeast direction, so that the warmer area lies in the southwest and the colder area in the northeast. Due to a more maritime climate in the western part of the study area, duration of intermediate seasons (early spring, spring, autumn, late autumn) is much longer than in the eastern part.

The influence of thermal inertia of the Baltic and the Black Seas is evident on the maps of start dates. All the climatic seasons, except early spring, start earlier in the coastal region than further inland. The earlier onset of early spring on the coast can be explained by the influence of ice-free sea surface. The highest spatial gradients are typical for the start of winter.

The highest temporal variability is characteristic for start dates of winter and early spring, when the standard deviation is about $2 \mathrm{wk}$, and the lowest variability is observed for start dates of spring, autumn and late autumn (standard deviation 10 to $11 \mathrm{~d}$ ). Duration of winter is the most variable in time.

\subsection{Trends}

Some statistically significant trends in start date and duration of climatic seasons in the East European Plain have been detected. The most important of them is the shortening of winter and the shifting earlier of the start date of early spring. During the short period (1946-1995), early spring has started earlier by up to 1 mo in Estonia, Latvia, and in western Russia. During the long period (1881-1995), in addition to this trend, a significant shift earlier of the start date of spring has been observed. All these trends are in good accordance with well-known trends of increasing winter and spring air temperatures in that region.

\subsection{Regionalisation}

The territory of the East European Plain is regionalised using PCA for start dates of climatic seasons. Regions with coherent fluctuations are distinguished for every season separately and for all seasons together. Results indicate that beginning dates of climatic seasons are rather coherent in central and southern parts of the East European Plain. Different fluctuations are observed in northern Russia. In a first step, climatic zones are distinguished-Temperate and Sub-Arctic Zones. Only the 3 northernmost stations belong to the latter zone. In the next step, the Temperate Zone is divided into 2 sub-zones - boreal and subboreal. The zones and sub-zones are divided into regions mostly in a west-east direction, depending on the continentality of the climate (Atlantic influence).

\subsection{Influence of atmospheric circulation}

Large-scale atmospheric circulation is a leading factor in determining start date and duration of climatic season every year. Its impact is highest in winter and in early spring. Prevalence of zonal circulation, i.e. westerlies, is related to mild winters and an early start of early spring, and meridional circulation causes cold winters with a late start of early spring. Negative correlation coefficients between parameters of intensity of westerlies and start date of early spring are below -0.5 . As was expected, the closest correlation is found in the western part of the study area.

The start date of spring is determined by 2 factors of atmospheric circulation. The residual effect of the previous winter influences the start date of spring. An intensive zonal circulation induces mild winters and an early start of spring. For example, start date of spring has a close negative correlation with NAO and AO indices in January, February and March. This effect is observed in the northern and western part of the study area.

At the time of onset of spring, in April and May (in northern Russia), not zonal but meridional circulation has the most significant influence on the start of spring. Northerly circulation (Form C) causes a late start, and southerly and easterly circulation (Form E) an earlier one.

Relationship between atmospheric circulation and start of summer is weaker. Prevalence of westerlies (Circulation Form W) in May and June is related to late start of summer in the Baltic states, while Form E corresponds to early start of summer. Circulation Form $\mathrm{C}$ has a significant positive correlation in the southern part of the East European Plain in April, in the central part, in May, and in the northern part, in June.

Strong westerlies result in the earlier start of autumn. There is a significant negative correlation with Form W in August and September, especially in the western part of the East European Plain. Late start of autumn is connected with Circulation Form E.

The start dates of late autumn and winter have an opposite dependence on zonal circulation in comparison with autumn. Correlation is positive, i.e. high intensity of westerlies leads to their retardation. Meridional circulation forms are related to earlier onset of late autumn and winter.

In general, there are 2 regions in the East European Plain that are influenced much more strongly by atmospheric circulation-northern Russia and the western part of the study area (Estonia, Latvia, Lithua- 
nia, Belarus, Ukraine, western Russia). Central Russia and the SE regions have a lower correlation with circulation parameters.

The western regions are mostly affected by westerlies, which bring an earlier start of early spring and autumn, and a later start of summer, late autumn and winter. Northerly airflow retards the start of early spring and advances that of winter. Southeasterly circulation (Form E) causes a late start of early spring, spring, autumn, and winter, and an early start of summer.

In northern Russia, mostly meridional circulation influences the onset of climatic seasons. The earlier starts of early spring, autumn, and late autumn are related to northerly circulation, while southerly circulation causes an earlier start of spring and summer.

Acknowledgements. This study is funded by the POSITIVE project of the E.U. Fifth Framework Programme and by the Estonian Science Foundation (Grant No. 4347).

\section{LITERATURE CITED}

Barnston AG, Livezey RE (1987) Classification, seasonality and persistence of low-frequency atmospheric circulation patterns. Mon Weather Rev 115:1083-1126

Carter TR (1998) Changes in the thermal growing season in Nordic countries during the past century and prospects for the future. Agric Food Sci Finland 7:161-179

Flohn H (1942) Witterung und Klima in Deutschland. Verlag von S Hirzel, Leipzig

Galahov NN (1959) Study on structure of climatic seasons of a year. Izdatel'stvo Akademii Nauk SSSR, Moscow (in Russian)

Girs AA (1971) Many-year fluctuations of the atmospheric circulation and long-term hydro-meteorological forecasts. Gidrometeoizdat, Leningrad (in Russian)

Hlavaè V (1975) Eine neue Methode zur objektiven Beurteilung der säkularen Schwankungen und Abnormalitäten der Lufttemperatur und der Sonnenfleckenrelativzahlen und ihre Anwendung für die 200jährigen Prager Temperaturreiche. Geofysikalni Sbornik 23:371-565

Hurrell JW, van Loon H (1997) Decadal variations in climate

Editorial responsibility: Clare Goodess,

Norwich, United Kingdom associated with the North Atlantic Oscillation. Clim Change 36:301-306

Jaagus J, Ahas R (2000) Space-time variations of climatic seasons and their correlation with the phenological development of nature in Estonia. Clim Res 15:207-219

Jones PD, Briffa KR (1995) Growing season temperatures over the former Soviet Union. Int J Climatol 15:943-959

Jones P, Jónsson T, Wheeler D (1997) Extension to the North Atlantic Oscillation using early instrumental pressure observations from Gibraltar and South-West Iceland. Int J Climatol 17:1433-1450

Kalnicky RA (1987) Seasons, singularities, and climatic changes over the midlatitudes of the northern hemisphere during 1899-1969. J Clim Appl Meteorol 26:1496-1510

Kożuchowski K, Marciniak K (1988) Variability of mean monthly temperatures and semi-annual precipitation totals in Europe in relation to hemispheric circulation patterns. Int J Climatol 8:191-199

Lamb HH (1972) Climate: present, past and future, Vol 1. Fundamentals and climate now. Methuen, London

Lewik P (1996) Thermal seasons of the year in southern Poland-tendencies of the terms and duration. Zeszyty Naukowe Uniwersitetu Jagiellonskiego Prace Geograficzne 102:355-358

Menzel A (2000) Trends in phenological phases in Europe between 1951 and 1996. Int J Biometeorol 44:76-81

Menzel A, Fabian P (1999) Growing season extended in Europe. Nature 397:659

Raik A (1963) Climatic seasons in Estonia. Acta Comment Univ Tartu 144:33-44 (in Estonian, abstract in English)

Roltsch WJ, Zalom FG, Strawn AJ, Strand JF, Pitcairn MJ (1999) Evaluation of several degree-day estimation methods in California climates. Int J Biometeorol 42:169-176

Schwartz MD, Reiter BE (2000) Changes in North American spring. Int J Climatol 20:929-932

Sladek I (1990) Changes of duration and timing of some temperature seasons of the year in Prague. In: Brazdil R (ed) Climatic change in the historical and the instrumental periods. Masaryk University, Brno, p 194-196

Temnikova NS (1958) The climate of the Latvian S.S.R. Gidrometeoizdat, Riga (in Russian)

Thompson WJ, Wallace JM (1998) The Arctic Oscillation signature in the wintertime geopotential height and temperature fields. Geophys Res Lett 25:1297-1300

Vangengeim GJ (1952) Principles of the macro-circulation method for long-term meteorological forecasts in the Arctic. Trudy AANII 34:11-66 (in Russian)

Submitted: June 4, 2002; Accepted: November 16, 2002 Proofs received from author(s): January 6, 2003 